\title{
PT-Flax (phenotyping and TILLinG of flax): development of a flax (Linum usitatissimum L.) mutant population and TILLinG platform for forward and reverse genetics
}

Maxime Chantreau ${ }^{1,2}$, Sébastien Grec ${ }^{1,2}$, Laurent Gutierrez ${ }^{3}$, Marion Dalmais ${ }^{4}$, Christophe Pineau ${ }^{5}$, Hervé Demailly ${ }^{3}$, Christine Paysant-Leroux ${ }^{6}$, Reynald Tavernier ${ }^{5}$, Jean-Paul Trouvé ${ }^{6}$, Manash Chatterjee ${ }^{7,8}$, Xavier Guillot ${ }^{9}$, Véronique Brunaud ${ }^{4}$, Brigitte Chabbert ${ }^{10,11}$, Olivier van Wuytswinkel ${ }^{12}$, Abdelhafid Bendahmane ${ }^{4}$, Brigitte Thomasset ${ }^{13}$ and Simon Hawkins ${ }^{1,2^{*}}$

\begin{abstract}
Background: Flax (Linum usitatissimum L.) is an economically important fiber and oil crop that has been grown for thousands of years. The genome has been recently sequenced and transcriptomics are providing information on candidate genes potentially related to agronomically-important traits. In order to accelerate functional characterization of these genes we have generated a flax EMS mutant population that can be used as a TILLinG (Targeting Induced Local Lesions in Genomes) platform for forward and reverse genetics.

Results: A population of 4,894 M2 mutant seed families was generated using 3 different EMS concentrations $(0.3 \%, 0.6 \%$ and $0.75 \%)$ and used to produce $M 2$ plants for subsequent phenotyping and DNA extraction. 10,839 viable M2 plants (4,033 families) were obtained and 1,552 families (38.5\%) showed a visual developmental phenotype (stem size and diameter, plant architecture, flower-related). The majority of these families showed more than one phenotype. Mutant phenotype data are organised in a database and can be accessed and searched at UTILLdb (http://urgv.evry.inra.fr/UTILLdb). Preliminary screens were also performed for atypical fiber and seed phenotypes. Genomic DNA was extracted from 3,515 M2 families and eight-fold pooled for subsequent mutant detection by ENDO1 nuclease mis-match cleavage. In order to validate the collection for reverse genetics, DNA pools were screened for two genes coding enzymes of the lignin biosynthesis pathway: Coumarate-3-Hydroxylase $(\mathrm{C} 3 \mathrm{H})$ and Cinnamyl Alcohol Dehydrogenase (CAD). We identified 79 and 76 mutations in the C3H and CAD genes, respectively. The average mutation rate was calculated as $1 / 41 \mathrm{~Kb}$ giving rise to approximately 9,000 mutations per genome. Thirty-five out of the 52 flax cad mutant families containing missense or codon stop mutations showed the typical orange-brown xylem phenotype observed in CAD down-regulated/mutant plants in other species. (Continued on next page)
\end{abstract}

\footnotetext{
*Correspondence: simon.hawkins@univ-lille1.fr

1Université Lille Nord de France, Lille 1 UMR 1281, Villeneuve d'Asca cedex F-59650, France

${ }^{2}$ INRA UMR, 281 Stress Abiotiques et Différenciation des Végétaux Cultivés, Villeneuve d'Ascq F-59650, France

Full list of author information is available at the end of the article
}

\section{Biomed Central}

(c) 2013 Chantreau et al.; licensee BioMed Central Ltd. This is an open access article distributed under the terms of the Creative Commons Attribution License (http://creativecommons.org/licenses/by/2.0), which permits unrestricted use, distribution, and reproduction in any medium, provided the original work is properly cited. 
(Continued from previous page)

Conclusions: We have developed a flax mutant population that can be used as an efficient forward and reverse genetics tool. The collection has an extremely high mutation rate that enables the detection of large numbers of independant mutant families by screening a comparatively low number of M2 families. The population will prove to be a valuable resource for both fundamental research and the identification of agronomically-important genes for crop improvement in flax.

Keywords: Flax, TILLinG, Mutants, Fiber, Lignin, Lignan, Oil, Fatty acids

\section{Background}

Flax (Linum usitatissimum L.) is an economically important oil and fiber crop that has been domesticated and grown by mankind for thousands of years. Oil extracted from flax seeds (linseed) is a considerable source of the omega-3 fatty acid, $\alpha$-linolenic acid (ALA) and seeds also contain biologically active lignans with beneficial effects on human health [1]. Flax phloem fibers have cell walls rich in cellulose and are used for textiles (linen) and for reinforcing composite polymers as an environmentally-friendly substitute for glass fibers [2]. Flax is also used as a biological model to study the molecular mechanisms involved in the formation of hypolignified secondary cell walls characteristic of different fiber species (e.g. flax, hemp, jute, kenaf etc.) [3-6].

Recently a number of different flax resources and approaches including high-density microarray platforms, physical and genetic maps, molecular markers, metabolomics and proteomics [6-12] have been developed. The recent sequencing of the genome [13] has also opened the way for flax genomics leading to rapid advances in the structural identification of genes and gene families $[14,15]$. However, while all of these approaches allow the identification of large numbers of genes potentially involved in a wide variety of different biological processes, the confirmation of their biological role(s) requires functional characterization. Flax can be genetically engineered and a limited number of genes have been up-/down-regulated in this species thereby providing important functional information on the role of these genes [5,16,17]. In order to accelerate functional characterization of genes potentially associated with different agronomical traits for crop improvement we have developed a chemically mutagenized (EMS) flax population and TILLinG (Targeting Induced Local Lesions IN Genomes) platform.

TILLinG (Targeting Induced Local Lesions IN Genomes) is a high-throughput reverse genetic method used to obtain an allelic series of a targeted mutated gene in a mutagenized population $[18,19]$. Chemical mutagenesis is complementary to other approaches such as T-DNA insertion or radiation and has been applied to a wide range of different plant species [20-24]. Currently, the most usual detection method depends on the use of the specific mis-match endonuclease ENDO1 to detect chemically induced SNPs. Nevertheless, high throughput sequencing by NGS technologies coupled with variant detection algorithms is also starting to be used to detect such mutations $[25,26]$. The development of such an approach in flax is timely since although this species can be transformed by Agrobacterium, the process is time consuming and relatively inefficient [27]. Ethane Methyl-Sulphonate (EMS) has been previously used as a chemical mutagen to introduce genetic variability into flax, but has not yet been used for reverse genetics [28].

In this paper, we present the development and characterization of a flax EMS mutagenized population. Visual phenotyping and the successful identification of a large number of cad and $c 3 h$ lignin gene mutants validated the use of our population as a valuable forward and reverse genetics tool. The use of this population in subsequent studies will greatly facilitate the functional characterization of different targeted genes in this economically important species.

\section{Results}

\section{Production and phenotyping of the EMS Flax mutant population}

Preliminary tests and kill curve analyses (Additional file 1) were performed on flax (Linum usitatissimum L. cv Diane) seeds to determine appropriate EMS concentrations as previously described [29-32]. Based on these results 3 different EMS percentages (0.3\%, $0.6 \%$ and $0.75 \%)$ were used to mutagenize 10,000 flax seeds. These mutagenized seeds were sown and gave rise to 5,000 M1 plants. M2 seeds were collected from M1 plants and all the seeds produced by an individual M1 plant were pooled to constitute the corresponding M2 family. After seed collection from M1 plants, 4,894 M2 different seed families were obtained and used as the basis for the flax TILLinG resource.

Five (0.3, 0.6\% EMS) and 3 (0.75\% EMS) seeds from each M2 family were then sown and grown under greenhouse conditions to produce M2 plants for phenotyping and DNA extraction. Altogether, a total of 10,839 M2 plants distributed in 4,033 families $(0.3 \%-1,700$ families, $0.6 \%-1,409$ families, $0.75 \%$ - 924 families, Table 1, Additional file 2) was obtained. Seeds from 861 M2 families (17.6\%) did not germinate. All M2 plants were individually phenotyped on 
Table 1 Constitution of the M2 mutant population and percentage sterility for each EMS concentration

\begin{tabular}{ccc}
\hline \% EMS & Number of $\mathbf{M} \mathbf{2}$ families & Percentage sterility \\
\hline 0.3 & 1,700 & 6.3 \\
0.6 & 1,409 & 13.5 \\
0.75 & 924 & 18.4 \\
\hline
\end{tabular}

the basis of 6 main categories and 13 sub-categories (Table 2) at 2 months after germination. Mutant families were compared to WT plants grown under identical conditions in the same greenhouse.

Of the 4,033 M2 families, 1,552 (38.5\%) showed a visual phenotype (Figures 1 and 2). The most represented phenotypes were observed in stems (size and diameter - 65\%), leaves (shape and colour - 46.1\%) and plant architecture (branching internode size $-26.1 \%$ ), followed by flowerrelated phenotypes (late flowering and/or fruit formation, colour, morphology - 9\%), hypocotyl size (3.5\%) and cotyledons (shape and number $-1.8 \%$ ). A majority (55.2\%) of the families show multiple phenotype modifications (Figure 1). Approximately 8.6\% (937) M2 plants were sterile and analyses indicated that sterility varied depending upon EMS concentration ranging from 6.31\% (0.3\% EMS) to $18.36 \%$ (0,75\% EMS) (Table 1).

Data on flax mutant phenotypes were introduced into the UTILLdb database and can be consulted at http://urgv. evry.inra.fr/UTILLdb.

\section{Flax lignin gene TILLinG}

For reverse genetics, leaves of individual M2 plants were collected and pooled by families for DNA extraction. M3 seeds were collected for long-term storage and production of further material. To estimate mutation density and

Table 2 Criteria of Phenotyping categories used to describe the Flax M2 mutant population

\begin{tabular}{ll}
\hline Category & Sub-category \\
\hline Cotyledon: & Number \\
& Shape \\
Hypocotyl: & Size \\
Stem: & Size \\
& Diameter \\
& Colour \\
Leaf: & Shape \\
& Colour \\
Architecture: & Branching type \\
& Inter-nodes \\
Flowering/Fruit: & Inflorescence \\
& Petal colour \\
& Reproductive organs \\
\hline
\end{tabular}

validate the flax population for future reverse genetics in this species, two genes were TILLed. Since flax is cultivated for both its seeds and its bast fibers and cell wall lignin content is an important factor in bast fiber quality, we decided to TILL two lignin genes (coumarate3-hydroxylase, C3H and cinnamyl alcohol dehydrogenase, $C A D)$. $\mathrm{C} 3 \mathrm{H}$ acts early in the monolignol biosynthetic pathway and plays a key role in the production of $\mathrm{G}$ and $\mathrm{S}$ lignin monomers whereas CAD catalyses the final step in the production of the lignin monomers (monolignols) [33].

Based on currently available sequence data (http://www. phytozome.net/) provided by whole genome sequencing, three $\mathrm{C} 3 \mathrm{H}$ and seventeen $C A D$ genes can be identified in the flax genome. For $\mathrm{C} 3 \mathrm{H}$ we decided to screen for mutations in [Phytozome : Lus10033524] the flax ortholog of the Arabidopsis thaliana CYP98A3 [Tair : At2G40890.1] involved in lignin and flavonoid biosynthesis [34]. In order to identify the flax $C A D$ gene most likely involved in lignification, we established a phylogenetic tree containing CAD proteins from Arabidopsis thaliana, Populus trichocarpa and Linum usitatissimum (Figure 3). CAD proteins can be divided into 5 classes [35] with functional proof for the involvement of class 1 proteins in lignification. Four $L u C A D$ genes were present in this class and we therefore decided to screen for mutations in the flax gene [phytozome : Lus10027864] showing the highest similarity with AtCAD4 [Tair : AT3G19450.1] and AtCAD5 [Tair : AT4G34230.1].

The CODDLE program (Codons Optimized to Discover Deleterious Lesions) combined with the PRIMER 3 tool were used to define the region within our two genes, with the most probability of a deleterious G/C to A/T transition and to design PCR primers compatible with the ENDO1 approach. A region of 1,077 Nt (1170-2247) was identified in the $\mathrm{C} 3 \mathrm{H}$ [Phytozome : Lus10033524] gene. For the CAD gene [Phytozome : Lus10027864], CODDLE targeted a region between position 38 and 1336 in the genomic sequence, corresponding to the dehydrogenase alcohol domain. However, given sequence redundancy between different flax $C A D$ genes in this region we chose to target the region between positions 828 and 1791. This region is composed of a nucleotide binding domain involved in cofactor binding and a catalytic domain involved in substrate binding [36].

A total of $150 C A D$ and $C 3 H$ mutants was obtained by screening for mutations with the mismatch-specific endonuclease ENDO1 as previously described [37]. Sixty-three, 49 and 39 mutations were detected in the $0.3 \%, 0.6 \%$ and $0.75 \%$ EMS populations, respectively. One cad family $(0,6 \%)$ contained 2 mutations. Mutation densities varied between $1 / 49 \mathrm{~kb}$ and $1 / 30 \mathrm{~kb}$ depending on the EMS dose giving rise to an average value of 1 mutation per $41 \mathrm{~kb}$.

Almost all mutations were $\mathrm{G} / \mathrm{C}$ to $\mathrm{A} / \mathrm{T}$ transitions, as expected for EMS mutagenesis [38] and only one mutation 


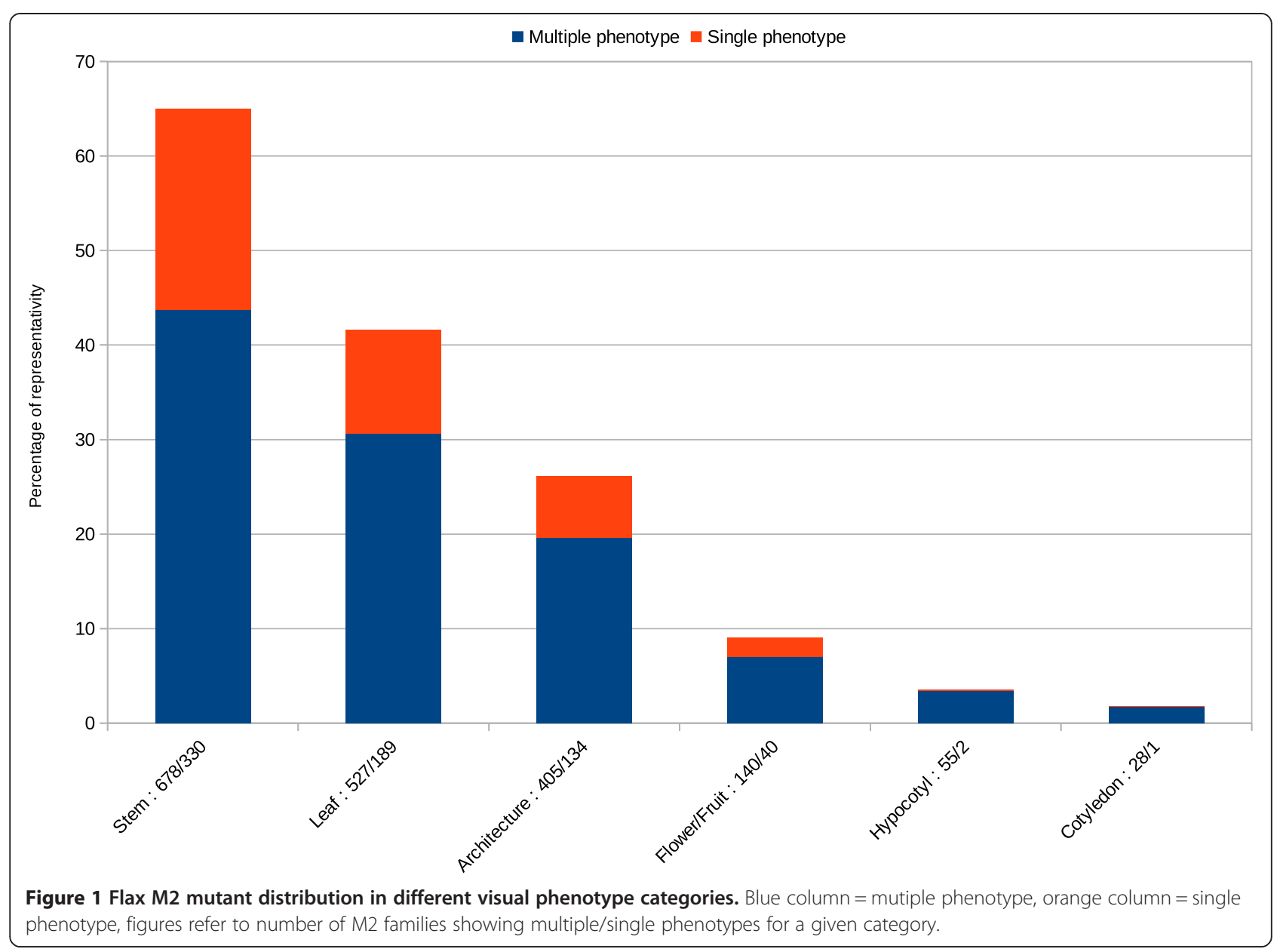

involved an $\mathrm{A} / \mathrm{T}$ to $\mathrm{G} / \mathrm{C}$ transition most likely due to low frequency EMS-mediated conversion of adenine to 3-methyladenosine and subsequent paring with cytosine as already observed in a previous study [39]. For mutations that occurred in exons, $66.7 \%$ were missense, $27.6 \%$ silent and $5.7 \%$ truncation mutations (Table 3). The mutation saturation (at the protein level) was calculated as $22.15 \%$ and $15.35 \%$ for the $C A D$ and $C 3 H$ amplicons, respectively. Mutations were regularly distributed along both amplicons, but showed a decrease in introns corresponding to a decrease in $G$ and $C$ nucleotides in these regions (Figure 4).

\section{EMS action on $\mathrm{G} / \mathrm{C}$ base pairs is influenced by the local environment}

In order to investigate the influence of local environment on EMS directed G/C to A/T transition we analyzed nucleotide composition flanking the mutated $\mathrm{G}$ bases $[40,41]$ (Figure 5). In the -1 position, $\mathrm{G}$ was more frequent (1.3x) and $\mathrm{T}$ was less frequent $(0.8 \mathrm{x})$ and in the +1 position, $\mathrm{A}$ was more frequent $(1.2 \mathrm{x})$ and $\mathrm{C}$ was less frequent $(0.8 \mathrm{x})$ than expected in agreement with previous results $[40,41]$. We also observed a bias among the observed and expected triplets composed of $-1 ; 0$ and +1 nucleotides (Table 4 ). The four most overrepresented mutated triplets were GGG, CGT, AGA and GGA, whereas the four most underrepresented triplets were AGT, CGC, TGT and CGG, corresponding to a higher frequency of purine bases in the overrepresented triplets and an increase in pyrimidine bases in the underrepresented triplets.

\section{From the genotype to the phenotype}

Having identified a large number of flax $C A D$ and $C 3 H$ mutants we then wished to know whether the mutations were associated with phenotypic modifications commonly observed in down-regulated plants or natural mutants in other species. Such data would also largely contribute to validating the interest of our mutant population for functional genomics in flax. For this we decided to focus on the $C A D$ mutants since both natural $C A D$ mutants and down-regulated $C A D$ plants in other species show a characteristic and easily observable red-brown coloration of the wood known as the 'brown midrib' phenotype. This coloration is mainly due to the accumulation of higher amounts of cinnamaldehydes into the lignin polymer rather 


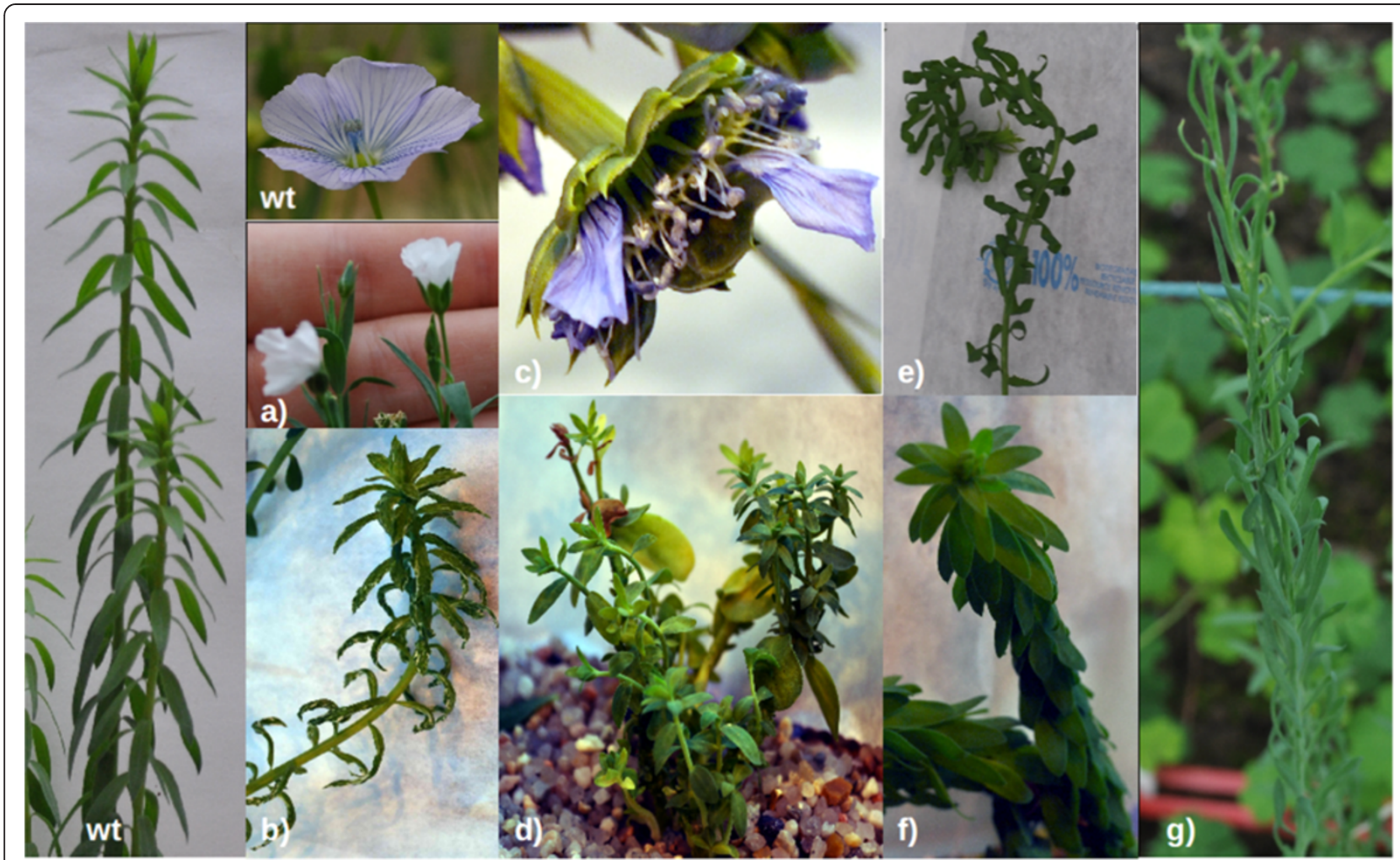

Figure 2 Examples of mutant flax phenotypes. a) Flowering mutant with altered petal colour; b) albino mutant; c) flowering mutant with additional reproductive and non-reproductive organs; d) mutant with branching and stem size changes; e) mutant with altered leaf morphology (rolled leaves); f) mutant with reduced internodes; $\mathbf{g}$ ) mutant with altered leaf morphology (elongated spoonbill shape).

than the more usual cinnamyl alcohols [42-48]. In contrast $\mathrm{C} 3 \mathrm{H}$ down-regulation in other species is associated with modifications in lignin structure but no visible phenotype [49]. Observation of stem cross-sections obtained from the 52 M2 mutant CAD families (108 plants) with a missense or stop codon mutation allowed us to identify 62 plants (belonging to 35 families) with a brown midrib phenotype (phenotype frequency $=0.57$ ). A comparable screening of a randomized subset of 33 non-CAD mutant families (94 plants) identified 6 plants with a weak brown midrib phenotype (phenotype frequency $=0.06$ ). These data strongly support the idea that the observed brown midrib phenotype results from a mutation within the targeted flax $C A D$ gene.

Individuals were then classed into 3 categories depending upon the intensity of the orange-brown coloration of the xylem tissues (Figure 6). The first group, corresponding to the most marked phenotype contained 11 individuals belonging to 9 mutant families ( 8 missense mutations and one codon stop mutation). Characteristics of these mutants are detailed in Table 5. The potential effect of the different missense mutations was then evaluated by using the SIFT software (Sorting Intolerant From Tolerant; http://sift.jcvi. org/) that uses PSI-BLAST alignments, and the PARSESNP software (Project Aligned Related Sequences and Evaluate
SNPs; http://www.proweb.org/parsesnp/) to provide a position-specific scoring matrix based on alignment blocks. PSSM scores were obtained by PARESSNP for 5 of the 8 missense mutations (Table 5). No scores were obtained for the G176R and P280L mutations, most probably because of a lack of alignment blocks. In addition to the codon stop mutation, 4 of the six PSSM scores are sufficiently high as to suggest that $\mathrm{CAD}$ protein activity could be negatively affected in the corresponding mutants. For the other $C A D$ mutants (categories 0, 2 and 3), 33\% of the predicted score (PSSM and Sift) were in agreement with the observed phenotype (Additional file 3).

\section{Discussion}

Flax is an ancient crop that has long been cultivated for its fibers and seeds. Current breeding programs aim at improving yield and quality in both fibers and seeds, as well as increasing resistance to different pathogens. The flax genome has recently been sequenced [13], physical and genetic maps have been developed and SNP markers identified [10]. In addition, flax specific microarrays, proteomics and metabolomics $[6,7,12,50,51]$ have also been used to increase our knowledge of flax biology. In this paper we report the development of a flax TILLinG platform for forward and reverse genetics in this economically 


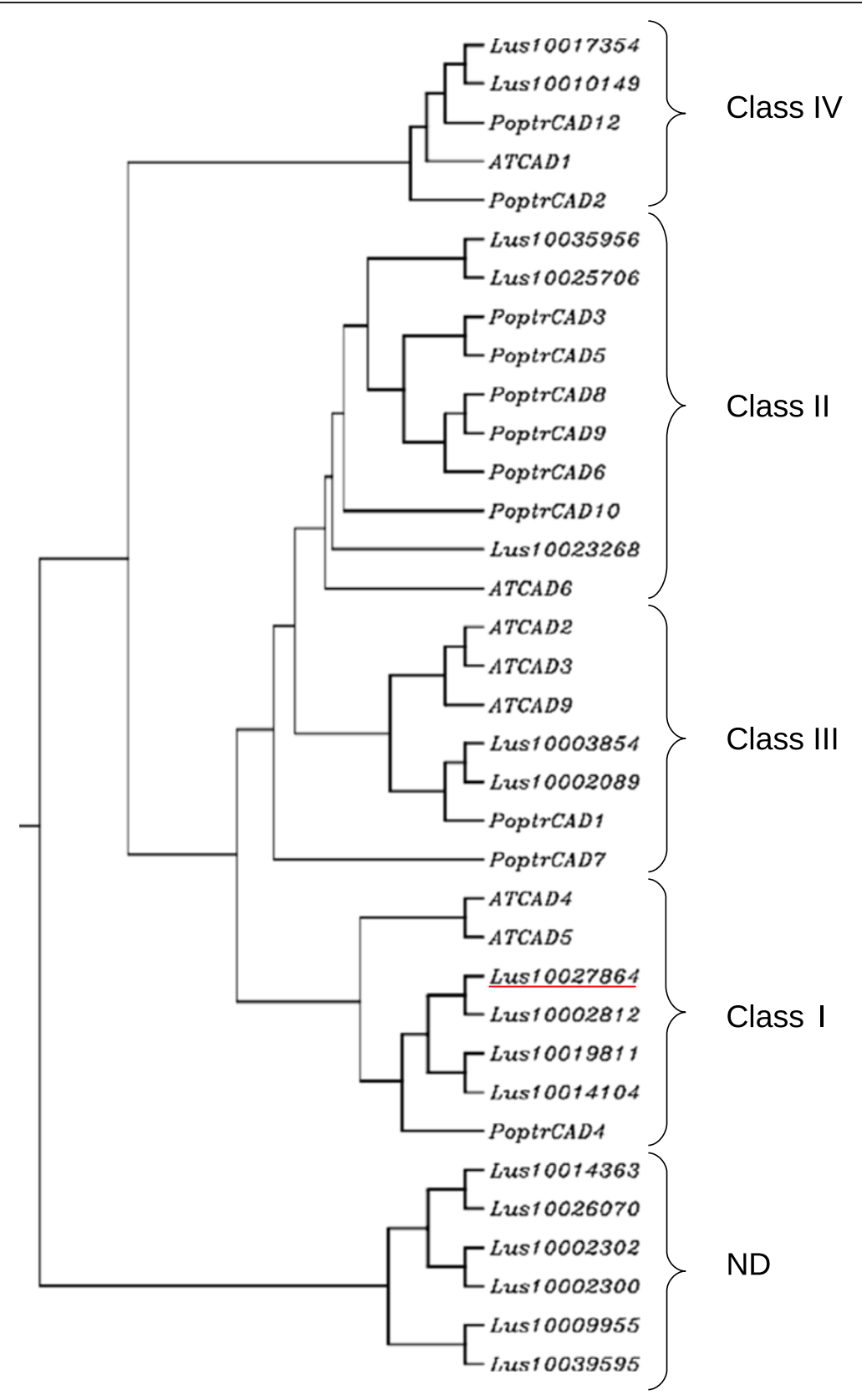

Figure 3 Rooted Phylogenetic tree (clustalW program with default parameters) of Arabidopsis thaliana, Poplar and Linum usitatissimum L. CAD proteins. The flax CAD protein selected for mutation discovery is underlined in red.

Table 3 Characteristics of mutations in CAD and $\mathrm{C} 3 \mathrm{H}$ amplicons

\begin{tabular}{|c|c|c|c|c|c|c|c|c|c|c|}
\hline \multirow[t]{2}{*}{ Target } & \multirow{2}{*}{$\begin{array}{l}\text { Amplicon } \\
\text { size }\end{array}$} & \multirow{2}{*}{$\begin{array}{l}\text { Identified } \\
\text { mutations }\end{array}$} & \multirow{2}{*}{$\begin{array}{l}\text { Mutation } \\
\text { frequency }\end{array}$} & \multirow{2}{*}{$\begin{array}{l}\text { Exon } \\
\text { size }\end{array}$} & \multirow{2}{*}{$\begin{array}{l}\% \text { of GC } \\
\text { in exons }\end{array}$} & \multirow{2}{*}{$\begin{array}{l}\text { Identified mutations } \\
\text { in exon }\end{array}$} & \multicolumn{3}{|c|}{ Type of mutation (exon) } & \multirow{2}{*}{$\begin{array}{c}\text { \% Mutation } \\
\text { saturation }\end{array}$} \\
\hline & & & & & & & Silent & Missense & Truncation & \\
\hline \multirow[t]{2}{*}{ CAD } & 869 & 76 & $1 / 40 \mathrm{~Kb}$ & 620 & 50.0 & 67 & 15 & 51 & 1 & 22.5 \\
\hline & & & & & & & $(22.4 \%)$ & $(76.1 \%)$ & $(1.5 \%)$ & \\
\hline \multirow[t]{2}{*}{$\mathrm{C} 3 \mathrm{H}$} & 981 & 79 & $1 / 44 \mathrm{~Kb}$ & 870 & 52.53 & 74 & 24 & 43 & 7 & 15.35 \\
\hline & & & & & & & (32.4\%) & $(58.1 \%)$ & $(9.5 \%)$ & \\
\hline
\end{tabular}

Silent mutations do not modify amino acids, missense mutations induce amino-acid modifications, truncation mutations induce a premature STOP codon in the reading frame. Percentage mutation saturation is calculated at the protein level as the number of amino acids modified compared to the total number of amino acids that can be potentially modified by EMS action. 


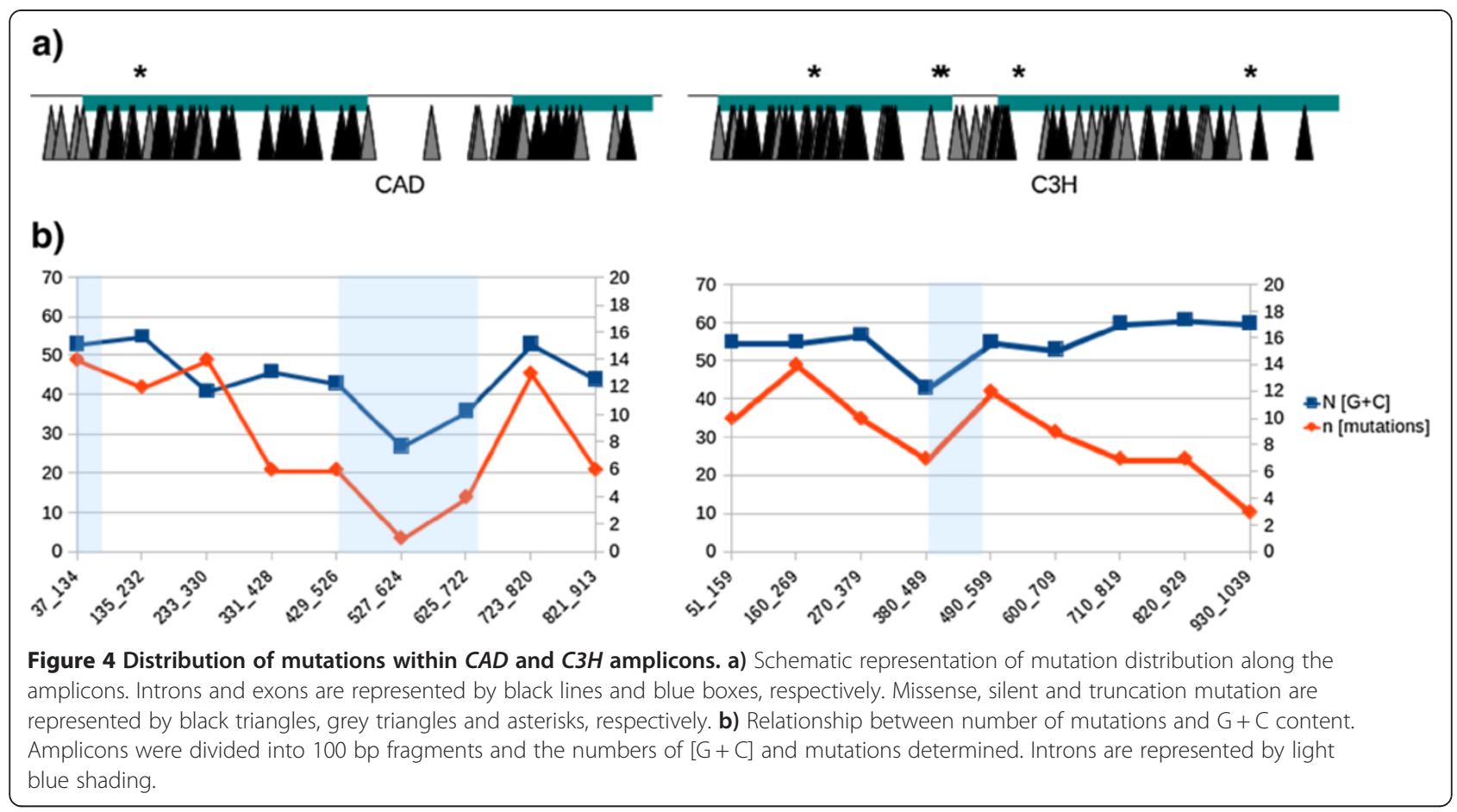

important species. 4,033 independent mutant families were phenotyped and the results organised in the UTILLdb database (http://urgv.evry.inra.fr/UTILLdb). UTILLdb is an open phenotypic and genomic mutant database containing information on mutant populations of pea [37], Brachypodium [52], tomato [53] and flax (this paper). The integration of our data into UTILLdb will enable flax breeders and scientists working on the flax model to search the database for particular mutant phenotypes. For example, detailed characterization of mutants showing altered stem/fiber morphology (Figures 2 and 7), and/or flower/seed modifications (Figures 2 and 8) will prove particularly interesting for scientists and breeders interested in fiber formation and seed oil/lignan biosynthesis. The database will be updated with information on mutations in specific genes that scientists will be able to access by sequence homology and/or keyword queries.

In order to validate the mutant collection as an efficient reverse genetics tool we extracted DNA from 3,515 lines and successfully TILLed 2 genes involved in lignin biosynthesis using the ENDO1 enzyme as previously described $[37,54]$. Our results indicated that our population had an average mutation rate of $1 / 41 \mathrm{~Kb}$. This is a high value as compared to mutation rates observed in other

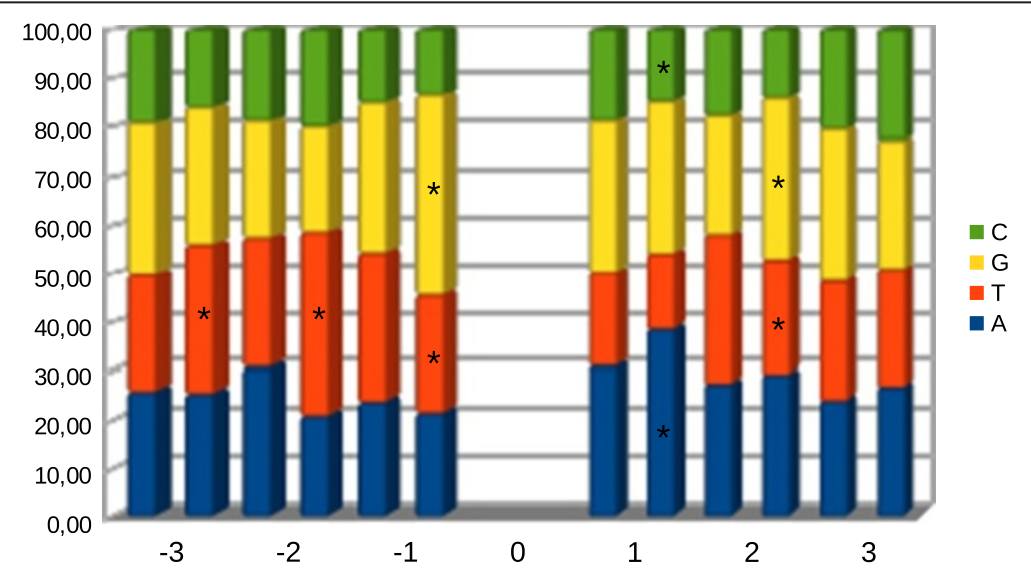

Figure 5 Expected and observed base frequencies around Gs. Expected (left column) and observed (right column) frequencies of C, G, T, A bases around all Gs or all mutated Gs. A divergence of $\geq 15 \%$ between expected and observed frequencies is indicated by an asterisk. 
Table 4 Frequency of triplet motif centred on all Gs and on mutated Gs. Ratios were obtained by comparing the frequency of a particular triplet centred on the mutated $G$ to the frequency of the same triplet centred on any available $\mathbf{G}$ in both amplicons

\begin{tabular}{cccc}
\hline Triplet & $\begin{array}{c}\text { Frequencies of triplet } \\
\text { centered on all Gs }\end{array}$ & $\begin{array}{c}\text { Frequencies of triplet } \\
\text { centered on mutated Gs }\end{array}$ & Ratio \\
\hline GGG & 7.69 & 14.29 & 1.86 \\
CGT & 2.83 & 5.19 & 1.83 \\
AGA & 6.68 & 10.39 & 1.56 \\
GGA & 10.32 & 14.94 & 1.45 \\
TGA & 8.50 & 8.44 & 0.99 \\
CGA & 5.26 & 5.19 & 0.99 \\
GGT & 6.68 & 6.49 & 0.97 \\
TGC & 5.47 & 5.19 & 0.95 \\
GGC & 6.07 & 5.19 & 0.86 \\
AGC & 4.86 & 3.90 & 0.80 \\
AGG & 8.30 & 6.49 & 0.78 \\
TGG & 10.53 & 7.14 & 0.68 \\
CGG & 4.45 & 2.60 & 0.58 \\
TGT & 5.87 & 3.25 & 0.55 \\
CGC & 2.63 & 0.65 & 0.25 \\
AGT & 3.85 & 0.65 & 0.17 \\
\hline
\end{tabular}

EMS-generated mutant populations (Table 6) and is similar to values observed for Triticum aestivum L.; Brassica napus L.; Avena sativa and Triticum durum L. However, all these populations are polyploid allowing them to tolerate loss-of-function mutations [55]. The highest mutation rates previously obtained in diploid species are those observed in Triticum monococcum $(1 / 92 \mathrm{~Kb})$ and Arabidopsis thaliana $(1 / 89 \mathrm{~Kb})$, approximately half that observed in our flax population.

With a genome size of approximately $370 \mathrm{Mb}$ [13] we can estimate that there will be an average of approximately 9,000 mutations per genome. Despite this high value, the majority $(81.6$ - 93.7\%) of the M2 population were viable and produced seeds suggesting that flax plants can support a high mutation level [55]. Although the high number of mutations per genome might be considered as a disadvantage since more back-crosses will be necessary to reduce total mutation number and identify genes potentially associated with a particular phenotype via a positional cloning approach, it also presents a number of advantages. Firstly, it considerably reduces the number of families that need to be screened to identify a mutant. For example, calculations show that only 56 families have to be screened to identify a missense mutation in a $1 \mathrm{~Kb}$ exon target and only 650 families need to be screened to identify a codon stop mutation, thereby reducing the overall time and costs spent on mutant identification. Secondly, the high mutation rate allows the identification of a large number of independent mutant families for a given gene in a reverse genetics strategy. For example, screening of our total population allowed us to identify $67 \mathrm{cad}$ mutants (exons only) and 74 c3h mutants (exons only). Subsequent characterization and identification of similar phenotypic modifications in the different lines provides strong evidence for a link between gene mutation and the observed phenotype. This was clearly demonstrated in the observation of our cad mutants where 35 (71\%) of the 52 families showing a missense or codon stop mutation in the $C A D$ gene showed the characteristic orange-brown coloration of xylem tissue previously observed in other $C A D$ down-regulated or mutant plants [42-48]. Although a previous report of CAD down-regulation in flax RNAi plants was associated with reduced lignin, somewhat surprisingly the authors did not report the presence/absence of a brown midrib phenotype [16]. This might be related to the relatively high (60-80\%) residual activity in these plants.

Preliminary analyses of our M3 cad mutants (data not shown) indicate that the mutation is heritable, segregates and can be correlated with brown/orange coloured xylem further establishing the link between mutation and phenotype in the flax population. Wet chemistry and

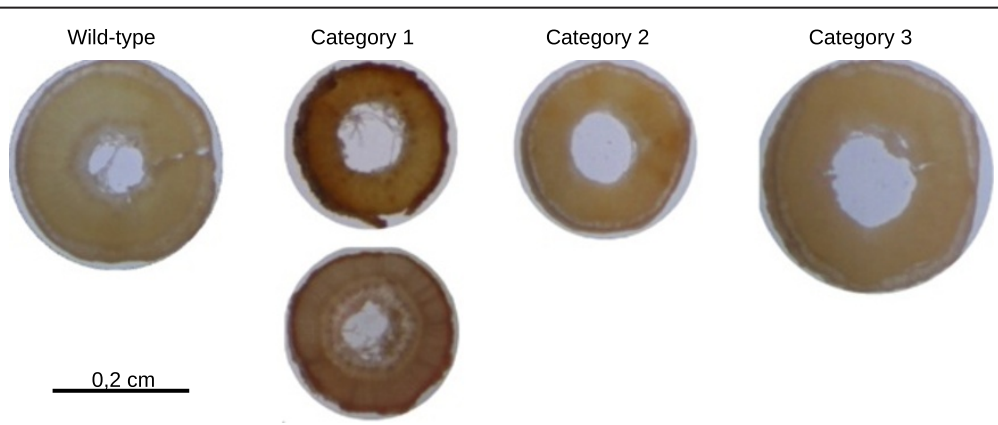

Figure 6 Brown-midrib phenotype of flax cad mutants. Examples of brown midrib phenotypes observed in stems of cad mutant lines. Mutants were grouped into 4 classes according to phenotype intensity $(1=$ strong, $2=$ medium, $3=$ weak, $0=$ absent). WT = wild-type flax stem. Bar $=2 \mathrm{~mm}$. 
Table 5 PSSM/Sift scores for CAD mutant lines showing category 1 brown midrib phenotype

\begin{tabular}{|c|c|c|c|c|c|c|}
\hline [EMS] & Family & No. Indiv $1 /$ total* & Mutation (Nt) & Mutation (AA) & PSSM difference & Sift score \\
\hline \multirow[t]{6}{*}{0,3} & 645 & $3 / 3$ & G1734A & E351K & 11.0 & 0.09 \\
\hline & 759 & $1 / 3$ & G1218A & V252I & 7.3 & 0.11 \\
\hline & 823 & $1 / 5$ & G1026A & G188R & 30.4 & 0.00 \\
\hline & 1021 & $1 / 4$ & G990A & G176R & _- & 0.00 \\
\hline & 1411 & $1 / 3$ & G936A & A158T & 11.0 & 0.09 \\
\hline & 1564 & $1 / 1$ & C1303T & P280L & - & 0.00 \\
\hline \multirow[t]{3}{*}{0.75} & 814 & $1 / 1$ & С999T & Q179Stop & damaging & damaging \\
\hline & 877 & $1 / 3$ & C1079T & $\mathrm{H} 205 \mathrm{Q}$ & 8.0 & 0.01 \\
\hline & 884 & $1 / 2$ & G1137A & G225R & 12.8 & 0.09 \\
\hline
\end{tabular}

PSSM scores and Sift scores were obtained with PARSESNP and SIFT programs, respectively. Scores in bold text are predicted to be damaging for protein activity while scores in normal text are predicted to be without effect. Mutations with no scores result from the lack of alignment block for the given position. *Number individual plants showing category 1 phenotype/total number plants phenotyped per family.

spectroscopy will allow confirmation of structural modifications in cell wall lignin in these mutants. Similar techniques will also be used to investigate potential changes to the lignin polymer in flax $c 3 h$ mutants. Down-regulation of this gene in other species is associated with an increase in lignin condensation and reduction in lignin $\mathrm{G}$ and $\mathrm{S}$ units $[49,78]$ and it will be particularly interesting to assess the effects in flax lignin that is already highly condensed and contains low amounts of S lignin [3].

\section{Conclusions}

In conclusion, the generated flax EMS population represents an important biological resource for both forward and reverse genetics in this species. A large number of mutants showing biologically-interesting phenotypes has been identified and genes have been successfully TILLed using ENDO1. Further targets can be identified from the literature, as well as on the basis of recent transcriptomic studies in flax that have identified different genes potentially involved in various biological processes $[6,7,9]$. The use of the flax EMS population to identify mutants will greatly accelerate functional characterization of agronomicallyinteresting genes in this crop species. In order to accelerate mutant identification in our flax EMS population, we are currently developing an approach based on high throughput sequencing using NGS.

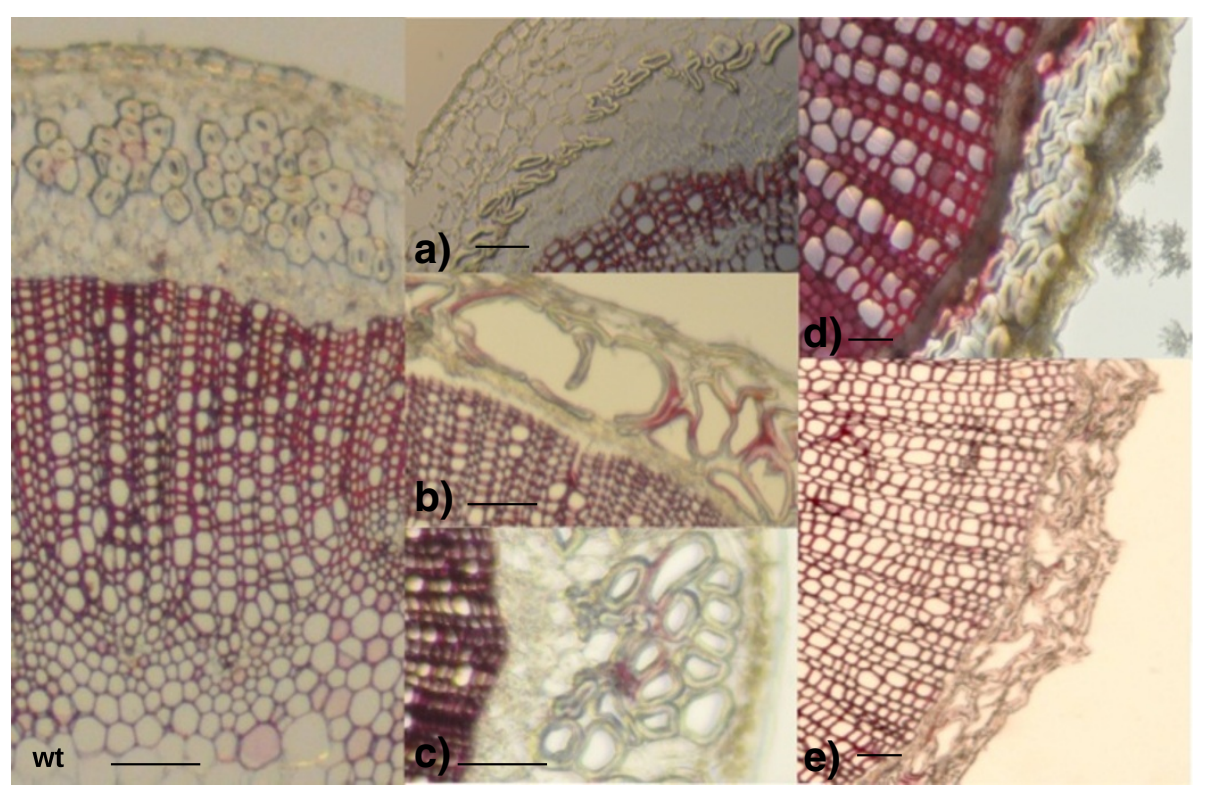

Figure 7 Examples of flax mutants showing morphological modifications in bast fibers. a) mutant with low fiber number and fibers with thin secondary cell walls; b) mutant with disorganised fiber bundles containing lacuna and thin-walled fibers with wide lumens; $\mathbf{c}$ ) mutant with fibers containing wide lumens; d) mutant with flattened bast fibers; e) mutant with disorganised fiber bundles containing wide lumens and thin secondary cell walls.Freehand cross-sections of mature flax stems were stained with Phloroglucinol- $\mathrm{HCl}$ and lignified cell walls appear coloured in red. $B a r=0,1 \mathrm{~mm}$. 


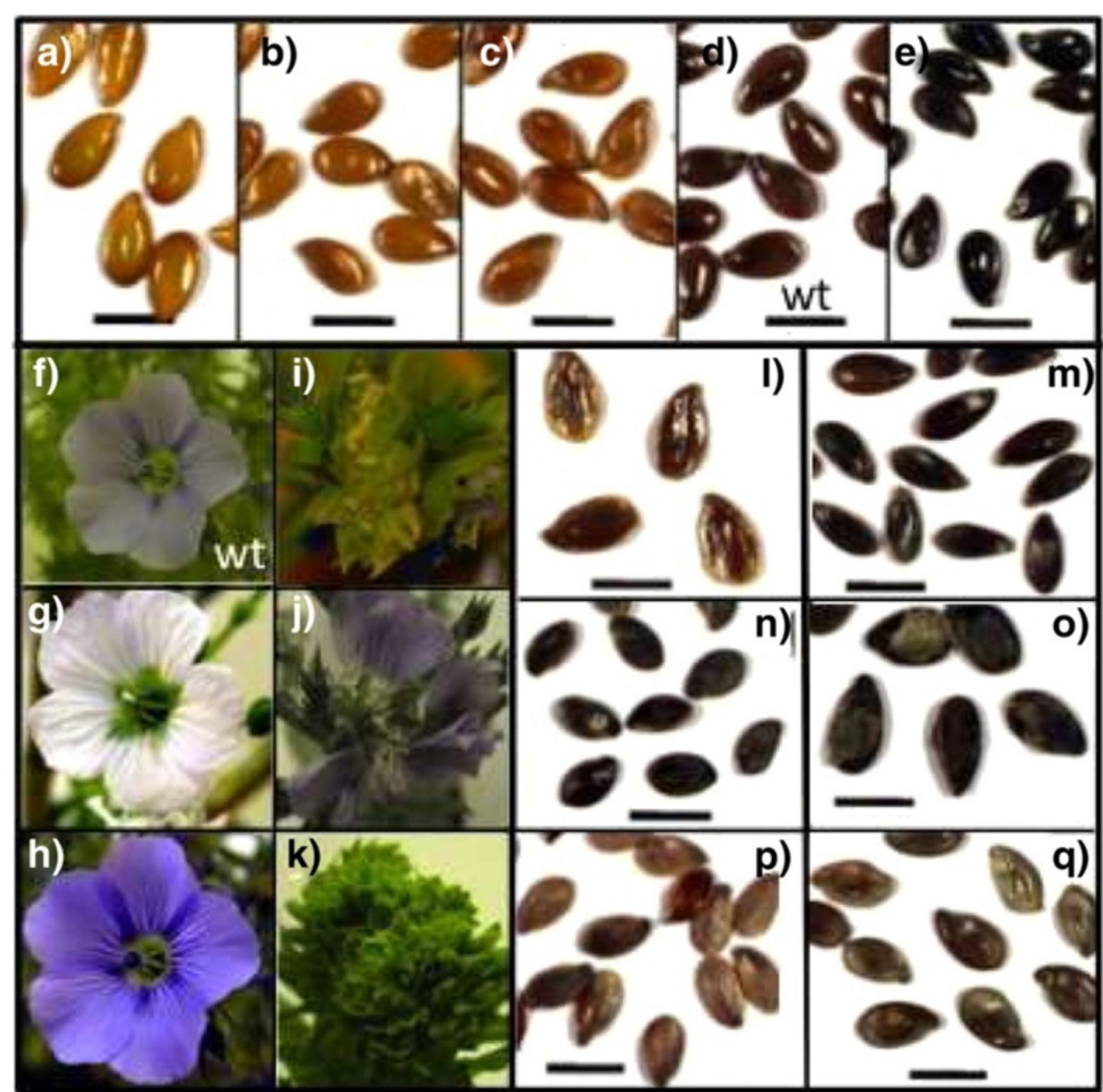

Figure 8 Examples of seed and flower phenotypes observed in the mutant population. 1-Seeds of mutants showing different colours from deep yellow (a) to deep black (e) and in between colour variation $(\mathbf{b}, \mathbf{c})$ including wild type $(\mathbf{d})(\mathrm{Bar}=0.5 \mathrm{~cm})$. 2-Flowers of mutants showing different colours from white $\mathbf{( g )}$ to parme variation $(\mathbf{f}, \mathbf{h})$. 3-Flowers of mutants with abnormal shape $\mathbf{( i ,}, \mathbf{j}, \mathbf{k})$. 4-Seeds of mutants showing variation in shape $(\mathbf{I}, \mathbf{m})(B a r=0.5 \mathrm{~cm})$. 5-Seed size variation between 2 specific mutants $(\mathbf{n}, \mathbf{0})(B a r=0.5 \mathrm{~cm})$. 6 -Seeds of mutants more or less filled $(\mathbf{p}, \mathbf{q})(\mathrm{Bar}=0.5 \mathrm{~cm})$.

\section{Methods}

\section{Mutagenesis and plant growth conditions}

Ten batches of one hundred seeds (Linum usitatissimum L. cv Diane) were treated with 8 different EMS concentrations $(0.25,0.3,0.5,0.6,0.75,0.8,1.0$ and $2.0 \%)$. Two exposure times ( 5 and $8 \mathrm{~h}$ ) were tested for two batches of different EMS concentration ( 5 h: 0.3, 0.6, 0.8, 1.0, 2.0\% EMS; 8 h: $0.25,0.5,0.75,1.0,2.0 \%$ EMS). Untreated seeds were used as reference. All seeds were washed with tap water $(3 \times 5$ mins, $1 \times 30$ mins) before transfer to wet Whatman paper in Petri dishes and incubation in a growth chamber at $20^{\circ} \mathrm{C}$ and $8 \mathrm{~h}$ photoperiod. Based on percentage germination, three treatments $(0.3 \%$ EMS/5 h, 0.6\% EMS/5 h and 0.75\% EMS/8 h) were selected representing different balances between germination and mutation rate. Mutagenized seeds (M1) were sown in the field for M2 seed production. Collected M2 seeds were sown under greenhouse conditions together with WT seeds for phenotyping and DNA extraction. M2 and M3 seeds are stored at $4^{\circ} \mathrm{C}$ under low humidity conditions and constitute the EMS flax mutant collection.

\section{Forward genetic screen}

Two months after germination, M2 families were scored for phenotypes distinct from the wild type. For each family, the most affected individual was phenotyped in detail and photographed. For identification of the brown midrib phenotype, freehand sections of individual stems were made from cad mutant family plants and compared to control sections under a stereo microscope. The presence of a brown-orange coloration in xylem tissue was considered indicative of the brown midrib phenotype and was noted from 1 to 3 depending upon the intensity of the coloration with 1 being the most intense. The category indicated for a family is that of the most intense phenotype observed in any single individual belonging to that family. 
Table 6 Mutation frequencies and ploidy levels in different published EMS plant populations

\begin{tabular}{|c|c|c|c|c|}
\hline Model & Ploidy level & EMS concentration (\%) & Frequency of mutation & Source \\
\hline Linum usitatissimum L. & $2 x$ & $-0.3,0.6,0.75 \%$ & $-1 / 41 \mathrm{~kb}$ & \\
\hline Triticum monococcum & $2 x$ & $-0.24 \%$ & $-1 / 92 \mathrm{~kb}$ & {$[32]$} \\
\hline \multirow[t]{5}{*}{ Triticum aestivum $\mathrm{L}$. } & $6 x$ & $-0.8 \%$ & $-1 / 47 \mathrm{~kb}$ & {$[31]$} \\
\hline & & $-0.6,0.9 \%$ & N.A & {$[56]$} \\
\hline & & $-0.9 \%$ & $-1 / 38 \mathrm{~Kb}$ & [57] \\
\hline & & $-0.5,0.6,0.7 \%$ & $-1 / 25 \mathrm{~Kb}$ & [58] \\
\hline & & $-0.75,1 \%$ & $-1 / 24 \mathrm{~Kb}$ & [59] \\
\hline \multirow[t]{2}{*}{ Triticum durum } & $4 x$ & $-0.7 \%$ & $-1 / 51 \mathrm{~Kb}$ & [57] \\
\hline & & $-0.75 \%$ & $-1 / 40 \mathrm{~Kb}$ & [59] \\
\hline \multirow[t]{4}{*}{ Brassica napus $\mathrm{L}$. } & $4 x$ & $-0.5,0.8,1,1.2 \%$ & -from $1 / 12$ to $1 / 22 \mathrm{~kb}$ & {$[60]$} \\
\hline & & $-1 \%$ & -from $1 / 27$ to $1 / 60 \mathrm{~kb}$ & \\
\hline & & $-0.3 \%$ & $1 / 130.8 \mathrm{~kb}$ & {$[61]$} \\
\hline & & $-0.6 \%$ & $1 / 41.5 \mathrm{~kb}$ & \\
\hline Brassica rapa & $2 x$ & $-0.3,0.4 \%$ & $1 / 60 \mathrm{~Kb}$ & {$[62]$} \\
\hline Brassica oleracea & $2 x$ & $-0.4 \%$ & $-1 / 447 \mathrm{~Kb}$ & [63] \\
\hline \multirow[t]{5}{*}{ Solanum lycopersicum } & $2 x$ & $-0.5 \%$ & $-1 / 1710 \mathrm{~kb}$ & [30] \\
\hline & & $-1.0 \%$ & $-1 / 737 \mathrm{~kb}$ & \\
\hline & & $-0.7 \%$ & $-1 / 574 \mathrm{~Kb}$ & [53] \\
\hline & & $-1 \%$ & $-1 / 322 \mathrm{~Kb}$ & \\
\hline & & $-1 \%$ & $-1 / 737 \mathrm{~Kb}$ & {$[64]$} \\
\hline \multirow[t]{2}{*}{ Cucumis melo L. } & $2 x$ & $-1 \%$ & $-1 / 1500 \mathrm{~Kb}$ & {$[65]$} \\
\hline & & $-1.5,2 \%$ & $-1 / 573 \mathrm{~Kb}$ & {$[66]$} \\
\hline Heliantus annus L. & $2 x$ & $-0.7 \%$ & $-1 / 475 \mathrm{~Kb}$ & {$[67]$} \\
\hline Arachis hypogaea & $4 x$ & $-0.4,1.2 \%$ & $-1 / 967 \mathrm{~Kb}$ & {$[68]$} \\
\hline \multirow[t]{4}{*}{ Arabidopsis thaliana } & $2 x$ & $-0.2 \%$ & $-1 / 415 \mathrm{~Kb}$ & [69] \\
\hline & & -Between 0.25 and $0.5 \%$ & $-1 / 89 \mathrm{~Kb}$ & {$[55]$} \\
\hline & & $-0.25,0.5 \%$ & $-1 / 300 \mathrm{~Kb}$ & {$[40]$} \\
\hline & & -Between 0.25 and $0.56 \%$ & $-1 / 180 \mathrm{~Kb}$ & {$[54]$} \\
\hline Avena sativa & $6 x$ & $-0.9 \%$ & $-1 / 30 \mathrm{~kb}$ & [70] \\
\hline Glycine max L. Merr. & $2 x$ & $-0.2,0.15 \%$ & $-1 / 485 \mathrm{~Kb}$ & [41] \\
\hline Lotus japonicus & $2 x$ & N.A & $-1 / 502 \mathrm{~Kb}$ & [71] \\
\hline Hordeum vulgare L. & $2 x$ & -Between 0.25 and $0.75 \%$ & $-1 / 500 \mathrm{~Kb}$ & [72] \\
\hline Medicago trunculata & $2 x$ & $-0.15 \%$ & $-1 / 400 \mathrm{~Kb}$ & [73] \\
\hline Sorghum bicolor & $2 x$ & -Between 0.1 and $0.3 \%$ & $-1 / 526 \mathrm{~kb}$ & [74] \\
\hline \multirow[t]{2}{*}{ Pisum sativum } & $2 x$ & $-0.25 \%$ & $-1 / 200 \mathrm{~kb}$ & {$[37]$} \\
\hline & & $-0.05 \%$ & $-1 / 669 \mathrm{~Kb}$ & [25] \\
\hline \multirow[t]{3}{*}{ Oriza sativa } & $2 x$ & $-1.5 \%$ & $-1 / 294 \mathrm{~Kb}$ & [75] \\
\hline & & $-0.8,1 \%$ & $-1 / 2000 \mathrm{~Kb}$ & [76] \\
\hline & & $-1.6 \%$ & $-1 / 1000 \mathrm{~Kb}$ & \\
\hline Hordeum vulgare $\mathrm{L}$. & $2 x$ & $-0.25,0.4$ & $-1 / 1000 \mathrm{~Kb}$ & [77] \\
\hline
\end{tabular}

Genomic DNA extraction and pooling

Leaf material was collected from individual M2 plants and pooled by family before being dried overnight at $65^{\circ} \mathrm{C}$ in a ventilated oven. Total DNA was extracted by using either the Dneasy Plant 96 Qiagen Kit (Qiagen, Hilden, Germany) or according to the protocol described by Carrier et al. [79]. DNA quality for each extraction was monitored by electrophoresis on $0.8 \%$ agarose gels. The 
Table 7 Primers used in TILLing experiments

\begin{tabular}{|c|c|}
\hline Primer & 5'-3' Primer sequence \\
\hline CAD external Forward primer & 5'-ACAGTTTGACCTGATGGAGCTCGAT-3' \\
\hline CAD external Reverse primer & 5'-GAAAACAAGTCAAATCGGACATAGG-3' \\
\hline $\mathrm{C} 3 \mathrm{H}$ external Forward primer & 5'-ATATTTACCAACCGGACTAACCTTG-3' \\
\hline $\mathrm{C} 3 \mathrm{H}$ external Reverse primer & 5'-AGTACAACACAATTCCAACTCTTCG-3' \\
\hline CAD internal Forward primer with M13 tail & 5'-CACGACGTTGTAAAACGACTITCGGTCCATCATCG-3' \\
\hline CAD internal Reverse primer with M13 tail & 5'-GATAACAATTTCACACAGGTATGGGTCTTCTCTTC-3' \\
\hline $\mathrm{C} 3 \mathrm{H}$ internal Forward primer with $\mathrm{M} 13$ tail & 5'-CACGACGTTGTAAAACGACACCACACTGAATTCGG-3' \\
\hline $\mathrm{C} 3 \mathrm{H}$ internal Reverse primer with $\mathrm{M} 13$ tail & 5'-GATAACAATTTCACACAGGCATGTAAGTCACCAGT-3' \\
\hline M13 Forward primer & 5'-CACGACGTTGTAAAACGAC-3' \\
\hline M13 Reverse primer & 5'-GGATAACAATTTCACACAGG-3' \\
\hline
\end{tabular}

The M13 tail sequence is indicated in bold text.

DNA of 3,515 M2 family was quantified with Picogreen (InVitrogen) using a M1000 microplate reader (TECANSwitzerland), normalized to $1 \mathrm{ng} \cdot \mu \mathrm{L}^{-1}$ and arrayed in a total of five 96 wells plates by an 8-fold pooling strategy (Additional file 4) using a GENESYS 150 workstation (TECAN-Switzerland).

\section{PCR amplification and mutation detection}

PCR amplification was based on nested-PCR and universal primers [80]. The first PCR amplification was performed with $1 \mathrm{ng}$ of pooled genomic DNA and target-specific primers (Table 7) in a $25 \mu \mathrm{l}$ volume. One microliter of the first PCR reaction was then used as a template for the second PCR using two set of primers: target-specific primers carrying universal M13 tail and M13 universal primers labelled at the $5^{\prime}$ end with infra-red dyes IRD700 and IRD800 (LI-COR, Lincoln, NE, USA). This PCR amplification was performed using $0.1 \mu \mathrm{M}$ of each primer in a $25 \mu \mathrm{L}$ volume and with the following two step program: $94^{\circ} \mathrm{C}$ for 3 minutes; 10 cycles at $94^{\circ} \mathrm{C}$ for $20 \mathrm{~s}$, primerspecific annealing temperature for $30 \mathrm{~s}$ and $72^{\circ} \mathrm{C}$ for $1 \mathrm{~min}$; and 25 cycles at $94^{\circ} \mathrm{C}$ for $20 \mathrm{~s}, 50^{\circ} \mathrm{C}$ for $30 \mathrm{~s}$ and $72^{\circ} \mathrm{C}$ for $1 \mathrm{~min}$; then a final extension at $72^{\circ} \mathrm{C}$ for 5 mins. PCR amplifications were verified on an agarose gel. Mutations were detected using a LI-COR 4300 DNA analyzer as previously described [66]. Individual mutations were confirmed and characterized by sequencing of DNA from individual M2 families.

\section{Bio-informatic sequence analyses}

Phylogenetic analyses of CAD proteins was performed using the clustalW program with default parameters (http:// www.clustal.org/clustal2/). The choice of gene regions to be TILLed and amplification primers were designed respectively using the CODDLE tool (Codons Optimized to Discover Deleterious Lesions; http://www.proweb. org/coddle/), primer 3 and OligoCalc system (http:// www.basic.northwestern.edu/biotools/oligocalc.html).
Potential effects of missense mutations were evaluated using the SIFT software (Sorting Intolerant From Tolerant; http://sift.jcvi.org/) and the PARSESNP software (Project Aligned Related Sequences and Evaluate SNPs; http:// www.proweb.org/parsesnp/).

\section{Supporting data}

The flax phenotypic data is publically available on the UTILLdb (http://urgv.evry.inra.fr/UTILLdb).

\section{Additional files}

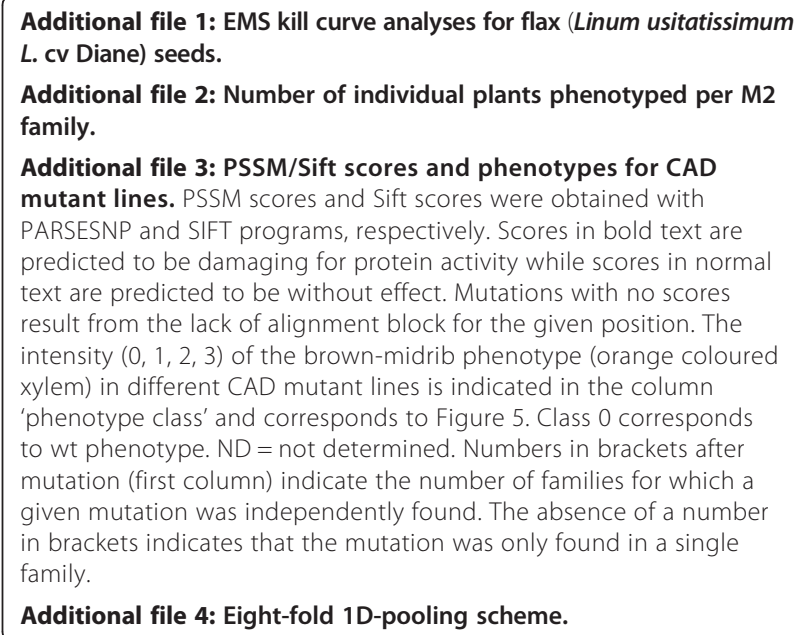

Additional file 4: Eight-fold 1D-pooling scheme.

\section{Competing interests}

The authors declare that they have no competing interests.

\section{Authors' contributions}

MChant. participated in plant phenotyping and sample collection. He did fiber screening and microscopy, data centralization for the UTILLdb, DNA extraction, all TILLinG experiments and data interpretation. He wrote the manuscript. SG managed the organization of plant phenotyping and sample collection, participated in sample collection, data centralization and DNA extraction. LG participated in plant phenotyping, sample collection, normalization of DNA pools and checked the final manuscript. MD provided scientific expertise and practical help on ENDO1 TILLinG and checked the 
final manuscript. RT managed greenhouse/field mutant plant production, participated in plant phenotyping and sample collection and checked the final manuscript. J-PT managed greenhouse/field mutant plant production. BT and OVW participated in plant phenotyping, in the obtention of seed collections, of the phenotyping analysis of all seed banks. MChat. Designed the EMS pilot dose experiments, selected the doses and checked the final manuscript. XG represented Laboulet in the PT-Flax consortium. VB organized the phenotypic data set in the UTILLdb web site. AB provided scientific expertise and advice on TILLinG and checked the final manuscript. $B C, H D, C T, C P, C P-L, B T$, OVW participated in plant growth, phenotyping and sample collection and checked the final manuscript. SH conceived and managed the PT-Flax project, participated in plant phenotyping and sample collection and edited the final manuscript. All authors read and approved the final manuscript.

\section{Acknowledgements}

Max. Chant. Gratefully acknowledges financial support of the Région Nord-Pas-de-Calais and the University of Lille 1 for the Ph.D. grant. SH gratefully acknowledges the financial support of the Agence Nationale de la Recherche (ANR) for the PT-Flax project (ANR-09-GENM-020-005). Man. Chat. would like to thank Dr S.K. Samanta, Prof Charles Spillane (NUIG) and Anish Kumar for general advice on flax, mutant population creation and pilot EMS dose experiments.

The authors would like to thank all the different people who contributed to the collection and phenotyping of the flax plants (Stephane Fénart, Anne-Sophie Blervacq, Rudy Huis, Guillaume Beaumont, Charles-Henri Biard, Laurent Rigolle, Géraldine Dambrey, Godfrey Neutelings, Michel Burtin, Romain Boucly, Valérie Devillers, Clarisse Toitot, Sébastien Acket, Melha Lazouk, Thi Mai Huong To, Elis elkassis, Pascal Boulnois).

\section{Author details}

${ }^{1}$ Université Lille Nord de France, Lille 1 UMR 1281, Villeneuve d'Ascq cedex F-59650, France. ${ }^{2}$ INRA UMR, 281 Stress Abiotiques et Différenciation des Végétaux Cultivés, Villeneuve d'Ascq F-59650, France. ${ }^{3}$ CRRBM, UFR des Sciences, UPJV, 33 rue Saint Leu, Amiens cedex 80039, France. ${ }^{4}$ URGV, Unité de Recherche en Génomique Végétale, Université d'Evry Val d'Essonne, INRA, 2 rue Gaston Crémieux CP 5708, Evry cedex 91057, France. ${ }^{5}$ LINEA, 20 Avenue Saget, Grandvilliers, 60 210, France. ${ }^{6}$ Terre de Lin, société cooperative agricole, Saint-Pierre-Le-Viger, 76 740, France. ${ }^{7}$ Bench Bio Pvt Ltd., c/o Jai Research Foundation, Vapi, Gujarat 396195, India. ${ }^{8}$ National University of Ireland Galway (NUIG), University Road, Galway, Ireland. ${ }^{9}$ Laboulet Semences, Airaines, 80 270, France. ${ }^{10}$ INRA, UMR614 Fractionnement des AgroRessources et Environnement, Reims F-51100, France. ${ }^{11}$ Université de Reims Champagne-Ardenne, UMR614 Fractionnement des AgroRessources et Environnement, Reims F-51100, France. ${ }^{12}$ EA 3900-BioPI, UFR des Sciences, UPJV, 33 rue Saint Leu, Amiens cedex 80039, France. ${ }^{13}$ CNRS-FRE 3580, GEC, Université de Technologie de Compiègne, CS 60319, Compiègnecedex 60203, France.

Received: 5 July 2013 Accepted: 9 October 2013 Published: 15 October 2013

\section{References}

1. Oomah BD: Flaxseed as a functional food source. J Sci Food Agric 2001, 81:889-894.

2. Baley C: Analysis of the flax fibres tensile behaviour and analysis of the tensile stiffness increase. Compos Part App/ Sci Manuf 2002, 33:939-948.

3. Day A, Ruel K, Neutelings G, Crônier D, David H, Hawkins S, Chabbert B: Lignification in the flax stem: evidence for an unusual lignin in bast fibers. Planta 2005, 222:234-245.

4. Roach MJ, Deyholos MK: Microarray analysis of flax (Linum usitatissimum L.) stems identifies transcripts enriched in fibre-bearing phloem tissues. Mol Genet Genomics MGG 2007, 278:149-165.

5. Roach MJ, Mokshina NY, Badhan A, Snegireva AV, Hobson N, Deyholos MK, Gorshkova TA: Development of Cellulosic Secondary Walls in Flax Fibers Requires B-Galactosidase. Plant Physiol 2011, 156:1351-1363.

6. Huis R, Morreel K, Fliniaux O, Lucau-Danila A, Fénart S, Grec S, Neutelings G, Chabbert B, Mesnard F, Boerjan W, Hawkins S: Natural hypolignification is associated with extensive oligolignol accumulation in flax stems. Plant Physiol 2012, 158:1893-1915.
7. Fenart S, Ndong Y-PA, Duarte J, Rivière N, Wilmer J, Wuytswinkel O, Van Lucau A, Cariou E, Neutelings G, Gutierrez L, Chabbert B, Guillot X, Tavernier R, Hawkins S, Thomasset B: Development and validation of a flax (Linum usitatissimum L.) gene expression oligo microarray. BMC Genomics 2010, 11:592.

8. Ragupathy R, Rathinavelu R, Cloutier S: Physical mapping and BAC-end sequence analysis provide initial insights into the flax (Linum usitatissimum L.) genome. BMC Genomics 2011, 12:217.

9. Venglat P, Xiang D, Qiu S, Stone SL, Tibiche C, Cram D, Alting-Mees M, Nowak J, Cloutier S, Deyholos M, Bekkaoui F, Sharpe A, Wang E, Rowland G, Selvaraj G, Datla R: Gene expression analysis of flax seed development. BMC Plant Biol 2011, 11:74.

10. Cloutier S, Ragupathy R, Miranda E, Radovanovic N, Reimer E, Walichnowsk A, Ward K, Rowland G, Duguid S, Banik M: Integrated consensus genetic and physical maps of flax (Linum usitatissimum L.). TAG Theor Appl Genet Theor Angew Genet 2012, 125:1783-1795.

11. Kumar S, You FM, Cloutier S: Genome wide SNP discovery in flax through next generation sequencing of reduced representation libraries. BMC Genomics 2012, 13:684.

12. Day A, Fénart S, Neutelings G, Hawkins S, Rolando C, Tokarski C: Identification of cell wall proteins in the flax (Linum usitatissimum) stem. Proteomics 2013, 13:812-825.

13. Wang Z, Hobson N, Galindo L, Zhu S, Shi D, McDill J, Yang L, Hawkins S, Neutelings G, Datla R, Lambert G, Galbraith DW, Grassa CJ, Geraldes A, Cronk QC, Cullis C, Dash PK, Kumar PA, Cloutier S, Sharpe AG, Wong GK-S, Wang J, Deyholos MK: The genome of flax (Linum usitatissimum) assembled de novo from short shotgun sequence reads. Plant J Cell Mol Biol 2012, 72:461-473.

14. Barvkar VT, Pardeshi VC, Kale SM, Kadoo NY, Gupta VS: Phylogenomic analysis of UDP glycosyltransferase 1 multigene family in Linum usitatissimum identified genes with varied expression patterns. BMC Genomics 2012, 13:175.

15. Babu PR, Rao KV, Reddy VD: Structural organization and classification of cytochrome P450 genes in flax (Linum usitatissimum L.). Gene 2013, 513:156-162.

16. Wróbel-Kwiatkowska M, Starzycki M, Zebrowski J, Oszmiański J, Szopa J: Lignin deficiency in transgenic flax resulted in plants with improved mechanical properties. J Biotechnol 2007, 128:919-934.

17. Day A, Neutelings G, Nolin F, Grec S, Habrant A, Crônier D, Maher B, Rolando C, David H, Chabbert B, Hawkins S: Caffeoyl coenzyme A Omethyltransferase down-regulation is associated with modifications in lignin and cell-wall architecture in flax secondary xylem. Plant Physiol Biochem PPB Société Française Physiol Végétale 2009, 47:9-19.

18. Henikoff S, Till BJ, Comai L: TILLING. Traditional Mutagenesis Meets Functional Genomics Plant. Physiol 2004, 135:630-636.

19. Wang TL, Uauy C, Robson F, Till B: TILLING in extremis. Plant Biotechnol J 2012, 10:761-772.

20. An G, Lee $\mathrm{S}, \mathrm{Kim}$ S-H, Kim S-R: Molecular genetics using T-DNA in rice. Plant Cell Physiol 2005, 46:14-22.

21. Busov V, Fladung M, Groover A, Strauss S: Insertional mutagenesis in Populus: relevance and feasibility. Tree Genet Genomes Vol 2005, 1:135-142.

22. Nath Radhamony R, Mohan Prasad A, Srinivasan R: T-DNA insertional mutagenesis in Arabidopsis: a tool for functional genomics. Electron $J$ Biotechnol 2005, 8(22):82-106.

23. Berenschot AS, Zucchi MI, Tulmann-Neto A, Quecini V: Mutagenesis in Petunia $\mathrm{x}$ hybrida Vilm. and isolation of a novel morphological mutant. Braz J Plant Physiol 2008, 20:95-103.

24. Morita R, Kusaba M, lida S, Yamaguchi H, Nishio T, Nishimura M: Molecular characterization of mutations induced by gamma irradiation in rice. Genes Genet Syst 2009, 84:361-370.

25. Triques K, Sturbois B, Gallais S, Dalmais M, Chauvin S, Clepet C, Aubourg S, Rameau C, Caboche M, Bendahmane A: Characterization of Arabidopsis thaliana mismatch specific endonucleases: application to mutation discovery by TILLING in pea. Plant J Cell Mol Biol 2007, 51:1116-1125.

26. Tsai H, Howell T, Nitcher R, Missirian V, Watson B, Ngo KJ, Lieberman M, Fass J, Uauy C, Tran RK, Khan AA, Filkov V, Tai TH, Dubcovsky J, Comai L: Discovery of Rare Mutations in Populations: TILLING by Sequencing. Plant Physiol 2011, 156:1257-1268.

27. Caillot S, Rosiau E, Laplace C, Thomasset B: Influence of light intensity and selection scheme on regeneration time of transgenic flax plants. Plant Cell Rep 2009, 28:359-371. 
28. Rowland GG: An EMS-induced low-linolenic-acid mutant in McGregor flax (Linum usitatissimum L.). Can J Plant Sci 1991, 71:393-396.

29. Harloff H-J, Lemcke S, Mittasch J, Frolov A, Wu JG, Dreyer F, Leckband G, Jung C: A mutation screening platform for rapeseed (Brassica napus L.) and the detection of sinapine biosynthesis mutants. Theor Appl Genet 2011, 124:957-969.

30. Okabe Y, Asamizu E, Saito T, Matsukura C, Ariizumi T, Brès C, Rothan C, Mizoguchi T, Ezura H: Tomato TILLING Technology: Development of a Reverse Genetics Tool for the Efficient Isolation of Mutants from MicroTom Mutant Libraries. Plant Cell Physiol 2011, 52:1994-2005.

31. Chen L, Huang L, Min D, Phillips A, Wang S, Madgwick PJ, Parny MAJ, Hu Y-G: Development and Characterization of a New TILLING Population of Common Bread Wheat (Triticum aestivum L.). PLOS ONE 2012, 7:e41570

32. Rawat N, Sehgal SK, Joshi A, Rothe N, Wilson DL, McGraw N, Vadlani PV, Li W, Gill BS: A diploid wheat TILLING resource for wheat functional genomics. BMC Plant Biol 2012, 12:205.

33. Fraser CM, Chapple C: The phenylpropanoid pathway in Arabidopsis. Arab Book 2011, 9:e0152.

34. Abdulrazzak N, Pollet B, Ehlting J, Larsen K, Asnaghi C, Ronseau S, Proux C, Erhardt M, Seltzer V, Renou J-P, Ullmann P, Pauly M, Lapierre C, WerckReichhart D: A coumaroyl-ester-3-hydroxylase Insertion Mutant Reveals the Existence of Nonredundant meta-Hydroxylation Pathways and Essential Roles for Phenolic Precursors in Cell Expansion and Plant Growth. Plant Physiol 2006, 140:30-48.

35. Eudes $A$, Pollet $B$, Sibout $R$, Do C-T, Séguin A, Lapierre C, Jouanin L: Evidence for a role of AtCAD 1 in lignification of elongating stems of Arabidopsis thaliana. Planta 2006, 225:23-39.

36. Youn B, Camacho R, Moinuddin SGA, Lee C, Davin LB, Lewis NG, Kang C: Crystal structures and catalytic mechanism of the Arabidopsis cinnamyl alcohol dehydrogenases AtCAD5 and AtCAD4. Org Biomol Chem 2006, 4:1687-1697.

37. Dalmais M, Schmidt J, Le Signor C, Moussy F, Burstin J, Savois V, Aubert G, Brunaud V, de Oliveira Y, Guichard C, Thompson R, Bendahmane A: UTILLdb, a Pisum sativum in silico forward and reverse genetics tool. Genome Biol 2008, 9:R43.

38. Sikora P, Chawade A, Larsson M, Olsson J, Olsson O: Mutagenesis as a Tool in Plant Genetics, Functional Genomics, and Breeding. Int J Plant Genomics 2011, 2011:1-13.

39. Krieg DR: Ethyl Methanesulfonate-Induced Reversion of Bacteriophage T4rii Mutants. Genet 1963, 48:561-580.

40. Greene EA, Codomo CA, Taylor NE, Henikoff JG, Till BJ, Reynolds SH, Enns LC, Burtner C, Johnson JE, Odden AR, Comai L, Henikoff S: Spectrum of Chemically Induced Mutations From a Large-Scale Reverse-Genetic Screen in Arabidopsis. Genet 2003, 164:731-740.

41. Le Signor C, Savois V, Aubert G, Verdier J, Nicolas M, Pagny G, Moussy F, Sanchez M, Baker D, Clarke J, Thompson R: Optimizing TILLING populations for reverse genetics in Medicago truncatula. Plant Biotechnol J 2009, 7:430-441.

42. Sibout R, Eudes A, Mouille G, Pollet B, Lapierre C, Jouanin L, Séguin A: CINNAMYL ALCOHOL DEHYDROGENASE-C and -D Are the Primary Genes Involved in Lignin Biosynthesis in the Floral Stem of Arabidopsis. Plant Cell Online 2005, 17:2059-2076.

43. Baucher M, Chabbert B, Pilate G, Doorsselaere JV, Tollier MT, Petit-Conil M, Cornu D, Monties B, Montagu MV, Inze D, Jouanin L, Boerjan W: Red Xylem and Higher Lignin Extractability by Down-Regulating a Cinnamyl Alcohol Dehydrogenase in Poplar. Plant Physiol 1996, 112:1479-1490.

44. Baucher M, Bernard-Vailhé MA, Chabbert B, Besle JM, Opsomer C, Van Montagu M, Botterman J: Down-regulation of cinnamyl alcohol dehydrogenase in transgenic alfalfa (Medicago sativa L.) and the effect on lignin composition and digestibility. Plant Mol Biol 1999, 39:437-447.

45. MacKay JJ, O'Malley DM, Presnell T, Booker FL, Campbell MM, Whetten RW, Sederoff RR: Inheritance, gene expression, and lignin characterization in a mutant pine deficient in cinnamyl alcohol dehydrogenase. Proc Natl Acad Sci U S A 1997, 94:8255-8260.

46. Zhang K, Qian Q, Huang Z, Wang Y, Li M, Hong L, Zeng D, Gu M, Chu C, Cheng Z: GOLD HULL AND INTERNODE2 Encodes a Primarily Multifunctional Cinnamyl-Alcohol Dehydrogenase in Rice. Plant Physiol 2006, 140:972-983.

47. Guillaumie $S$, Pichon $M$, Martinant J-P, Bosio M, Goffner $D$, Barrière $Y$ : Differential expression of phenylpropanoid and related genes in brown-midrib $\mathrm{bm} 1, \mathrm{bm} 2, \mathrm{bm} 3$, and bm4 young near-isogenic maize plants. Planta 2007, 226:235-250.
48. Jourdes M, Cardenas CL, Laskar DD, Moinuddin SGA, Davin LB, Lewis NG: Plant cell walls are enfeebled when attempting to preserve native lignin configuration with poly-p-hydroxycinnamaldehydes: Evolutionary implications. Phytochemistry 2007, 68:1932-1956.

49. Ralph J, Akiyama T, Kim H, Lu F, Schatz PF, Marita JM, Ralph SA, Reddy MSS, Chen F, Dixon RA: Effects of Coumarate 3-Hydroxylase Down-regulation on Lignin Structure. J Biol Chem 2006, 281:8843-8853.

50. Fenart S, Chabi M, Gallina S, Huis R, Neutelings G, Riviere N, Thomasset B, Hawkins S, Lucau-Danila A: Intra-platform comparison of 25-mer and 60-mer oligonucleotide Nimblegen DNA microarrays. BMC Res Notes 2013, 6:43.

51. Barvkar VT, Pardeshi VC, Kale SM, Kadoo NY, Giri AP, Gupta VS: Proteome profiling of flax (Linum usitatissimum) seed: characterization of functional metabolic pathways operating during seed development. J Proteome Res 2012, 11:6264-6276.

52. Brkljacic J, Grotewold E, Scholl R, Mockler T, Garvin DF, Vain P, Brutnell T, Sibout R, Bevan M, Budak H, Caicedo AL, Gao C, Gu Y, Hazen SP, Holt BF, Hong S-Y, Jordan M, Manzaneda AJ, Mitchell-Olds T, Mochida K, Mur LAJ, Park C-M, Sedbrook J, Watt M, Zheng SJ, Vogel JP: Brachypodium as a Model for the Grasses: Today and the Future. Plant Physiol 2011, 157:3-13.

53. Minoia S, Petrozza A, D'Onofrio O, Piron F, Mosca G, Sozio G, Cellini F, Bendahmane A, Carriero F: A new mutant genetic resource for tomato crop improvement by TILLING technology. BMC Res Notes 2010, 3:69.

54. Till BJ, Reynolds SH, Greene EA, Codomo CA, Enns LC, Johnson JE, Burtner C, Odden AR, Young K, Taylor NE, Henikoff JG, Comai L, Henikoff S: Large-Scale Discovery of Induced Point Mutations With High-Throughput TILLING. Genome Res 2003, 13:524-530.

55. Martín B, Ramiro M, Martínez-Zapater JM, Alonso-Blanco C: A high-density collection of EMS-induced mutations for TILLING in Landsberg erecta genetic background of Arabidopsis. BMC Plant Biol 2009, 9:147.

56. Sestili F, Botticella E, Bedo Z, Phillips A, Lafiandra D: Production of novel allelic variation for genes involved in starch biosynthesis through mutagenesis. Mol Breed 2010, 25:145-154

57. Uauy C, Paraiso F, Colasuonno P, Tran RK, Tsai H, Berardi S, Comai L, Dubcovsky J: A modified TILLING approach to detect induced mutations in tetraploid and hexaploid wheat. BMC Plant Biol 2009, 9:115.

58. Dong C, Dalton-Morgan J, Vincent K, Sharp P: A Modified TILLING Method for Wheat Breeding. Plant Genome J 2009, 2:39.

59. Slade AJ, Fuerstenberg SI, Loeffler D, Steine MN, Facciotti D: A reverse genetic, nontransgenic approach to wheat crop improvement by TILLING. Nat Biotechnol 2005, 23:75-81.

60. Harloff H-J, Lemcke S, Mittasch J, Frolov A, Wu JG, Dreyer F, Leckband G, Jung C: A mutation screening platform for rapeseed (Brassica napus L.) and the detection of sinapine biosynthesis mutants. Theor Appl Genet 2012, 124:957-969.

61. Wang N, Wang Y, Tian F, King GJ, Zhang C, Long Y, Shi L, Meng J: A functional genomics resource for Brassica napus: development of an EMS mutagenized population and discovery of FAE1 point mutations by TILLING. New Phytol 2008, 180:751-765.

62. Stephenson P, Baker D, Girin T, Perez A, Amoah S, King GJ, Østergaard L: A rich TILLING resource for studying gene function in Brassica rapa. BMC Plant Biol 2010, 10:62.

63. Himelblau E, Gilchrist EJ, Buono K, Bizzell C, Mentzer L, Vogelzang R, Osborn T, Amasino RM, Parkin IAP, Haughn GW: Forward and reverse genetics of rapid-cycling Brassica oleracea. TAG Theor Appl Genet Theor Angew Genet 2009, 118:953-961.

64. Gady AL, Hermans FW, Van de Wal MH, van Loo EN, Visser RG, Bachem CW: Implementation of two high through-put techniques in a novel application: detecting point mutations in large EMS mutated plant populations. Plant Methods 2009, 5:13

65. González M, Xu M, Esteras C, Roig C, Monforte AJ, Troadec C, Pujol M, Nuez F, Bendahmane A, Garcia-Mas J, Picó B: Towards a TILLING platform for functional genomics in Piel de Sapo melons. BMC Res. Notes 2011, 4:289.

66. Dahmani-Mardas F, Troadec C, Boualem A, Lévêque S, Alsadon AA, Aldoss AA Dogimont C, Bendahmane A: Engineering melon plants with improved fruit shelf life using the TILLING approach. PLOS One 2010, 5:e15776.

67. Sabetta W, Alba V, Blanco A: Montemurro C: sunTILL: a TILLING resource for gene function analysis in sunflower. Plant Methods 2011, 7:20.

68. Knoll JE, Ramos ML, Zeng Y, Holbrook CC, Chow M, Chen S, Maleki S, Bhattacharya A, Ozias-Akins P: TILLING for allergen reduction and improvement of quality traits in peanut (Arachis hypogaea L.). BMC Plant Biol 2011, 11:81. 
69. Bush SM, Krysan PJ: iTILLING: a personalized approach to the identification of induced mutations in Arabidopsis. Plant Physiol 2010, 154:25-35.

70. Chawade A, Sikora P, Bräutigam M, Larsson M, Vivekanand V, Nakash MA, Chen T, Olsson O: Development and characterization of an oat TILLING-population and identification of mutations in lignin and beta-glucan biosynthesis genes. BMC Plant Biol 2010, 10:86.

71. Perry J, Brachmann A, Welham T, Binder A, Charpentier M, Groth M, Haage K, Markmann K, Wang TL, Parniske M: TILLING in Lotus japonicus identified large allelic series for symbiosis genes and revealed a bias in functionally defective ethyl methanesulfonate alleles toward glycine replacements. Plant Physiol 2009, 151:1281-1291.

72. Gottwald S, Bauer P, Komatsuda T, Lundqvist U, Stein N: TILLING in the two-rowed barley cultivar "Barke" reveals preferred sites of functional diversity in the gene HvHox1. BMC Res Notes 2009, 2:258.

73. Porceddu A, Panara F, Calderini O, Molinari L, Taviani P, Lanfaloni L, Scotti C, Carelli M, Scaramelli L, Bruschi G, Cosson V, Ratet P, Larembergue H, De Duc $G$, Piano E, Arcioni S: An Italian functional genomic resource for Medicago truncatula. BMC Res Notes 2008, 1:129.

74. Xin Z, Li Wang M, Barkley NA, Burow G, Franks C, Pederson G, Burke J: Applying genotyping (TILLING) and phenotyping analyses to elucidate gene function in a chemically induced sorghum mutant population. BMC Plant Biol 2008, 8:103.

75. Till BJ, Cooper J, Tai TH, Colowit P, Greene EA, Henikoff S, Comai L: Discovery of chemically induced mutations in rice by TILLING. BMC Plant Biol 2007, 7:19.

76. Wu J-L, Wu C, Lei C, Baraoidan M, Bordeos A, Madamba MRS, RamosPamplona M, Mauleon R, Portugal A, Ulat VJ, Bruskiewich R, Wang G, Leach J, Khush G, Leung H: Chemical- and Irradiation-induced Mutants of Indica Rice IR64 for Forward and Reverse Genetics. Plant Mol Biol 2005, 59:85-97.

77. Caldwell DG, McCallum N, Shaw P, Muehlbauer GJ, Marshall DF, Waugh R: A structured mutant population for forward and reverse genetics in Barley (Hordeum vulgare L.). Plant J Cell Mol Biol 2004, 40:143-150.

78. Vanholme R, Morreel K, Ralph J, Boerjan W: Lignin engineering. Curr Opin Plant Biol 2008, 11:278-285.

79. Carrier G, Santoni S, Rodier-Goud M, Canaguier A, de Kochko A, DubreuilTranchant C, This P, Boursiquot J-M, Le Cunff L: An efficient and rapid protocol for plant nuclear DNA preparation suitable for next generation sequencing methods. Am J Bot 2011, 98:e13-15.

80. Wienholds E, van Eeden F, Kosters M, Mudde J, Plasterk RHA, Cuppen E: Efficient target-selected mutagenesis in zebrafish. Genome Res 2003, 13:2700-2707.

doi:10.1186/1471-2229-13-159

Cite this article as: Chantreau et al.: PT-Flax (phenotyping and TILLinG of flax): development of a flax (Linum usitatissimum L.) mutant population and TILLinG platform for forward and reverse genetics. BMC Plant Biology 2013 13:159.

\section{Submit your next manuscript to BioMed Central and take full advantage of:}

- Convenient online submission

- Thorough peer review

- No space constraints or color figure charges

- Immediate publication on acceptance

- Inclusion in PubMed, CAS, Scopus and Google Scholar

- Research which is freely available for redistribution 